\title{
"Special aspects of using hybrid financial tools for project risk management in Ukraine"
}

\begin{tabular}{|c|c|}
\hline \multirow{7}{*}{ AUTHORS } & Volodymyr Mishchenko iD https://orcid.org/0000-0002-8565-2686 \\
\hline & R http://www.researcherid.com/rid/N-4143-2018 \\
\hline & Svitlana Naumenkova (D https://orcid.org/0000-0001-8582-6044 \\
\hline & R https://publons.com/researcher/2083490/svitlana-naumenkova/ \\
\hline & Viktor Ivanov (D https://orcid.org/0000-0003-4121-0605 \\
\hline & R http://www.researcherid.com/rid/K-9180-2015 \\
\hline & levgen Tishchenko (D https://orcid.org/0000-0002-1580-4701 \\
\hline ARTICLE INFO & $\begin{array}{l}\text { Volodymyr Mishchenko, Svitlana Naumenkova, Viktor Ivanov and levgen } \\
\text { Tishchenko (2018). Special aspects of using hybrid financial tools for project risk } \\
\text { management in Ukraine. Investment Management and Financial Innovations, } \\
\text { 15(2), 257-266. doi:10.21511/imfi.15(2).2018.23 }\end{array}$ \\
\hline DOI & http://dx.doi.org/10.21511/imfi.15(2).2018.23 \\
\hline RELEASED ON & Friday, 15 June 2018 \\
\hline RECEIVED ON & Monday, 21 May 2018 \\
\hline \multirow[t]{2}{*}{ ACCEPTED ON } & Friday, 08 June 2018 \\
\hline & $(\mathrm{cc})$ EY-NO \\
\hline LICENSE & $\begin{array}{l}\text { This work is licensed under a Creative Commons Attribution-NonCommercial } 4.0 \\
\text { International License }\end{array}$ \\
\hline JOURNAL & "Investment Management and Financial Innovations" \\
\hline ISSN PRINT & $1810-4967$ \\
\hline ISSN ONLINE & $1812-9358$ \\
\hline PUBLISHER & LLC "Consulting Publishing Company "Business Perspectives" \\
\hline FOUNDER & LLC "Consulting Publishing Company "Business Perspectives" \\
\hline
\end{tabular}

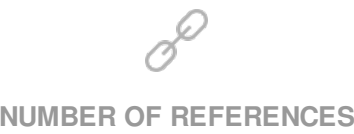

22
NUMBER OF FIGURES

0

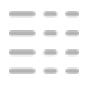

NUMBER OF TABLES

4

(C) The author(s) 2022. This publication is an open access article. 


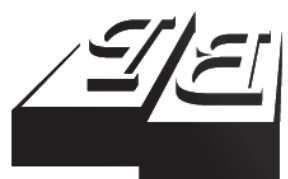

BUSINESS PERSPECTIVES

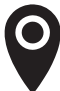

LLC "CPC "Business Perspectives" Hryhorii Skovoroda lane, 10, Sumy, 40022, Ukraine

www.businessperspectives.org

Received on: $21^{\text {st }}$ of May, 2018 Accepted on: $8^{\text {th }}$ of June, 2018

(C) Volodymyr Mishchenko, Svitlana Naumenkova, Viktor Ivanov, Ievgen Tishchenko, 2018

Volodymyr Mishchenko, Doctor of Economics, Professor, Department of Economics and Management, State Higher Education Institution "University of Banking", Ukraine.

Svitlana Naumenkova, Doctor of Economics, Professor, Department of Finance, Taras Shevchenko National University of Kyiv, Ukraine.

Viktor Ivanov, Doctor of Economics, Professor, Department of Credit Theory and Financial Management, Saint Petersburg State University, Russian Federation.

Ievgen Tishchenko, Ph.D. Student, State Higher Education Institution "University of Banking", Ukraine.

\section{(ㄷ)(1) (8)}

This is an Open Access article, distributed under the terms of the Creative Commons Attribution-NonCommercial 4.0 International license, which permits re-use, distribution, and reproduction, provided the materials aren't used for commercial purposes and the original work is properly cited.

Volodymyr Mishchenko (Ukraine), Svitlana Naumenkova (Ukraine),

Viktor Ivanov (Russian Federation), Ievgen Tishchenko (Ukraine)

\title{
SPECIAL ASPECTS OF USING HYBRID FINANCIAL TOOLS FOR PROJECT RISK MANAGEMENT IN UKRAINE
}

\begin{abstract}
The relevance of the article is due to the need of using non-traditional tools for capital raising and hedging financial risks in Ukrainian conditions that allow in vestors to protect themselves against possible losses during the entire life cycle of the investment project. The study is based on the National Bank of Ukraine statistical data, data of Ukrainian commercial banks, as well as on the authors' calculations based on empirical and economic-statistical methods. According to international practices, hybrid financial instruments were classified and the special aspects of their use in Ukraine were studied to manage the risks of project financing. Specific features of using the structured bonds for financing investment projects are determined based on the synthetic securitization scheme. The experience of Ukrainian banks was analyzed and the necessity to use financial instruments such as guarantees and letters of credit in risk management of project financing was substantiated. It has been established that forward contracts, currency swaps and over-the-counter currency options are the most acceptable instruments for hedging foreign exchange risks of project financing. Further studies of the problem should include the need for legislative regulation of using hybrid financial instruments, as well as methodological and regulatory support for the risk management of project financing at all stages of the investment project implementation.
\end{abstract}

Keywords

\section{JEL Classification G10, G32}

\section{INTRODUCTION}

The need to increase the investment activity of domestic companies calls for the search of new forms and methods of attracting a good deal of investment resources to the national economy. However, the overall investment climate is still unfavorable in the country due to the slow pace of economic reforms and increased political risks, and the investment attractiveness of many companies is low, which causes a significant increase in risks for all investment process participants. In this regard, there is a need of search and practical use of non-traditional, for Ukrainian conditions, tools for capital raising and hedging financial risks that allow investors to reduce risks and protect themselves against possible losses during the entire life cycle of the investment project.

In the project financing carried out by foreign corporations, the most common financial instruments used to attract investment resources are bank loans, including syndicated ones, issue of shares and corporate bonds, asset securitization, guarantee banking instruments, and derivative financial instruments. 
Recently, a variety of hybrid financial instruments have been widely used, which include, mainly, convertible bonds, and structured financial products using currency derivatives. Therefore, use of hybrid financial instruments in domestic practice in order to implement large investment projects is becoming particularly relevant.

\section{LITERATURE REVIEW}

Theoretical and practical aspects of using the hybrid financial instruments in the project risk management are given enough attention in the scientific literature. Yescombe (2014) set out the main methodological principles of project financing. The theoretical problems of managing project financing risks have been extensively studied by Crouhy, Galai, and Mark (2005), the problems of organizing risk management systems in commercial banks are widely investigated by Bessis (2015). Docherty and Viort (2013) analyzed how to understand and eliminate the failures in managing project financing risks, as well as develop their regulation to improve the banking organization. Strategic issues of bank portfolios safe management to increase investment attractiveness and ensure sustainable growth of banks have been investigated by Boberski (2010). Golin and Delhaise (2013) developed practical recommendations on credit analysis and credit risk management of project financing for bankers and investors.

Ghosh (2012), King (2014), devoted their work to risk management in commercial and retail banking services of banks, and, first of all, in managing loan portfolios risks of financial institutions that finance investment projects.

Yehorycheva, Kolodiziev, and Prasolova (2017) investigated the need to increase bank capital in order to reduce the investment risks of banks in Ukraine.

Currently, in the scientific literature, a lot of research is devoted to the problem of using asset securitization for managing project risks. First of all, it is necessary to emphasize the research by Davidson, Sanders, Wolff, and Ching (2004), in which the securitization process in terms of structuring and management is characterized, Fabozzi (1996) who paid attention to the use of asset-backed securities, as well as research articles by Mishchenko, Naumenkova, and Shapoval (2016), Jobst (2008), Kothari (2006), and others.
Studies of the influence of central banks on the project risk management in banking and the role of the private sector in managing systemic risks with a view to ensuring financial stability (Moenjak, 2016), studies on the management of investment activity risks in pro-cyclical monetary regulation (Mishchenko, Naumenkova, \& Lon, 2016).

Of practical interest are studies of country and political risks in project financing(Weltman, 2015; Sokolov \& Sokolova, 2016). Traditionally, the Basel Committee on Banking Supervision (BCBS, 2011), the Bank for International Settlements (BIS, 2004) and the World Bank Group (World Bank Group, 2012) pay great attention to the use of investment guarantees, letters of credit and hybrid financial instruments for risk management of project financing and reflect best practices and recommendations on using hybrid financial instruments in project financing for project risk management.

However, insufficient legislative regulation of using hybrid financial instruments, and the methodological and normative support of the risk management of project financing at all stages of the investment project implementation remain unsolved aspects of the project risk management in Ukraine.

\section{METHODS}

The study is based on the National Bank of Ukraine statistical data for the period 2014-2017, data of commercial banks of Ukraine for the periods 2006-2008 and 2014-2017, as well as on the authors' calculations based on the using a set of empirical and economic-statistical methods of scientific analysis.

A monographic method, methods of analysis and synthesis were used while studying theoretical and methodological aspects of project financing, as well as classifying and analyzing project risks and hybrid financial instruments used in risk management of project financing. 
In order to make a comparative assessment of using hybrid financial instruments in world practice and in Ukraine, when examining the best practices recommended by the Basel Committee on Banking Supervision, the Bank for International Settlements and World Bank Group, and when determining the specifics of using hybrid financial instruments in Ukraine, comparison method, analog approach and sampling method were used.

Economic and statistical methods were used to determine and quantify the relationships between individual phenomena and processes using hybrid financial instruments, guarantees, letters of credit and currency derivatives. To choose the type of securitization, to distribute risks and assess the advantages of individual hybrid financial instruments, the method of experimental calculation was used. To determine the effectiveness of issuing convertible bonds both from the investor's point of view and from the issuer's point of view, as well as to justify the structure of costs and cash flows arising in the process of asset securitization and the structured bonds issue, the analytical method and the method of expert assessments were used.

Methods of scientific abstraction and system-structural analysis were integrated in developing practical recommendations for improving the organizational, legal and financial aspects of using hybrid financial instruments for risk management of project financing in Ukraine.

\section{RESULTS}

Analysis of the practical use of hybrid financial instruments suggests that they have complex characteristics and, more often than not, are a combination of loan instruments and capital instruments. The peculiarity of their application is in the fact that they are both a source of obtaining additional financial resources and an instrument for protecting against the risks of changes in the interest rate, the exchange rate, the prices of goods or securities, etc.

In IFRS 9 (International Financial Reporting Standard), a hybrid financial instrument is viewed through the lens of a hybrid contract containing a combination of a simple financial instrument and a derivative, and the characteristics of a simple financial instrument are the basis for a hybrid contract. For example, when using fixed-income bonds, face value, coupon yield and maturity will be its unchanged characteristics.

The combination of a simple financial instrument with derivatives (forward contract, futures, options, warrants) allows for more flexible environment for meeting commitments, which allows to take into account changes on the different markets - stock, money, foreign exchange, commodity, and changes in asset prices in other sectors of the economy. Convertible bonds with exchange for common or preferred shares; use of a step-wise coefficient of bond conversion depending on the market price per share; multicurrency bonds, etc. can be examples of such financial instruments.

In the world practice of project financing on the basis of the convertible bonds issue, the following hybrid tools are mainly used:

- convertible project bonds, subject to exchange for ordinary shares of companies participating in the project. Such bonds are most often used in the case of project financing under the "limited recourse project" scheme, where money flows generated by other assets of project participants (sponsors) can be partially the sources of debt repayment;

- multicurrency project bonds, which are used in project financing by participants who are residents of different countries, as a result of which the par value redemption is made in the currency of the country in which the investment project is carried out;

- project bonds with a variable coupon, the rate of which depends on the expected profitability of the project and the terms of its implementation.

The convertible bonds are those, the terms of issue of which provide for their exchange for shares of the company. Advantages of using convertible bonds for the issuer consist in reducing the cost of borrowing capital, and for investors - in reducing 
the risk of increasing the exchange value of shares and obtaining additional income. An additional method of insuring investors' risks is the acquisition of the corporate rights of the joint-stock company in the future, which makes the investment process similar to the mezzanine financing mechanism.

In the conditional calculation of the efficient use of convertible bonds (see Table 1), the bond issuer attracts UAH 50 million for the transfer of corporate rights in the amount of UAH 20 million. The average yield on bonds is $11.2 \%$, and the credit market rate is $15 \%$. Thus, the saving of the bond issuer in resource attraction will make UAH 1.9 million. The potential income of the investor will be UAH 7.4 million, that is, $14.8 \%$ per annum, which is comparable to the average market yield. Thus, there is a redistribution of incomes and mutual insurance of risks of the bond issuer and the investor having any reliable provision in terms of company shares subject to conversion.

In addition to attracting resources and hedging financial risks, the use of hybrid financial instruments allows to obtain additional tax benefits. First of all, this concerns preferred securities with monthly (Monthly Income Preferred Securities (MIPS)) and quarterly (Quarterly Income Preferred Securities
(QUIPS)) income payment. In order to implement such a mechanism, the investing company creates a subsidiary abroad, which issues preferred shares. The income from the sale of these shares is received by the parent company as a loan or by buying the bonds issued. As a rule, in many countries, payments for credits and bonds are not taxed, which serves as an additional source of revenue for the company.

According to the Ukrainian legislation, SSAP 13 (Statement of Standard Accounting Practice), "Financial Instruments", approved by the Ministry of Finance of Ukraine, does not clearly define the conditions for recognition, accounting valuation and accounting rules for hybrid financial instruments. At the same time, a complex financial instrument is characterized as that containing a component of a financial liability and a component of an equity instrument.

This approach stipulates that in project financing, project bonds used to raise capital may be a component of a financial liability, and a component of an equity instrument - shares or another financial instrument whose change in fair value (or its associated cash flow) necessitates the use of one or several instruments for hedging financial risks.

Adhering to the approach outlined in SSAP 13, the hedging of the project cash flow resulting from the

Table 1. Conditional calculation of the income of a bond issuer and an investor when using convertible bonds (on an annualized basis)

Source: Estimated by the authors.

\begin{tabular}{|c|c|c|}
\hline \multicolumn{2}{|r|}{ Indicators } & \multirow{2}{*}{$\frac{\text { Value }}{20}$} \\
\hline 1. & Cost of equity to be converted, UAH mln & \\
\hline 2. & Convertible bond emission, UAH mln - total, including: & 50 \\
\hline & - $1^{\text {st }}$ tranche & 20 \\
\hline & - $\quad 2^{\text {nd }}$ tranche & 30 \\
\hline 3. & Bond yield, \% - on average, including: & 11.2 \\
\hline & - $1^{\text {st }}$ tranche & 10 \\
\hline & - $\quad 2^{\mathrm{n}} \mathrm{d}$ tranche & 12 \\
\hline 4. & The conversion of bonds into shares ratio - the average value, including: & 2.5 \\
\hline & $1^{\text {st }}$ tranche & 2 \\
\hline & - $\quad 2^{\text {nd }}$ tranche & 3 \\
\hline 5. & Average market interest rate on the credit, $\%$ & 15 \\
\hline 6. & Potential expenses of the bond issuer for credit repayment, UAH mln & 7.5 \\
\hline 7. & Expenses of the bond issuer for interest payment (and investor's income from the bond purchase), UAH mln & 5.6 \\
\hline 8. & Potential savings of the bond issuer on interest, $\cup A H$ mln & 1.9 \\
\hline 9. & Average market interest rate on deposits, \% & 9 \\
\hline 10. & Potential income of the investor as a result of share acquisition (including annual deferral), UAH mln & 1.8 \\
\hline 11. & Total potential income of the investor, UAH mln & 7.4 \\
\hline
\end{tabular}


investment project implementation can be considered as a hedge of the change in cash flows relative to the risk associated with a recognized asset, liability or with another predictable transaction that will affect change in the amount of net project income.

Complex financial instruments used to hedge project finance risks include securitized project bonds, which are issued to attract additional resources to finance corporations and support longterm financial decisions.

In the scientific literature, securitization is understood as a method of attracting additional investment resources, as well as redistributing risks by transforming certain types of assets into liquid financial instruments by issuing secured bonds that generate payments. The main types of securitization include traditional and synthetic (Davidson, Sanders, Wolff, \& Ching, 2004). Traditional securitization is considered as a kind of structured financing and risk redistribution, in which assets are transferred to a specially created institution, SPV, which on its behalf issues debt and sells it to investors, thus, attracting additional financial resources. Synthetic securitization can be used both to redistribute financial risks (credit default swap and total return swap) and to attract resources based on credit risk transfer by using instruments such as Credit Linked Notes and Loan Participation Notes (Mishchenko, Naumenkova, \& Shapoval, 2016).

Internationally, securitized assets such as Residential Mortgage-Backed Securities (RMBS), Commercial Mortgage-Backed Securities (CMBS), Asset-Backed Securities (ABS), and Collateralized Debt Obligations (CDOs) are the most widely used. For the purpose of managing project financing risks, securitized bonds secured by commercial mortgages (CMBS), as well as leasing contracts or other promissory notes (CDOs) are of the greatest interest.

There is a two-way assessment of securitization risks while managing project financing risks: in terms of the influence on the originator's capital issuing bonds, and in terms of the impact on the overall financial risks of the entire investment project or its individual participants.
The methodological basis for assessing the impact of securitization risks on bank capital is reflected in "The International Convergence of Capital Measurement and Capital Standards: A Revised Framework" by the Bank of International Settlements. According to this document, using traditional securitization, the originator bank may exclude securitized claims from the calculation of risk-weighted assets in case of transferring a significant credit risk associated with securitization to a third party (The Bank for International Settlements, 2004).

In a synthetic securitization using collateral, guarantees or credit derivatives to hedge the claims underlying them, only acceptable collateral can be recognized, and the instruments used to transfer the credit risk should not limit the total amount of credit risk transferred.

According to the Bank for International Settlements recommendations, a fairly broad list of them is applicable to acceptable financial instruments of collateral: funds on bank accounts; gold; debt securities that are rated by a reputable rating agency or listed in an authoritative exchange; shares and convertible bonds, which are included in the main index of the stock exchange; shares of Undertaking for Collective Investment in Transferable Securities (UCITS) and mutual funds, which carry out daily quotations of their securities (The Bank for International Settlements, 2004).

In the world practice, considerable experience has been accumulated in the use of structured bonds to finance investment projects. However, in Ukraine, this process began only in 2006. Privatbank, Alfabank, Ukrsibbank, Nadra, Finance \& Credit, and Ukrsotsbank are the most active in issuing structured bonds based on a synthetic securitization scheme. In the period 2006-2008, Ukrainian banks securitized their assets based on the issuing Loan Participation Notes at the sum of USD 24 bln and Credit Notes worth approximately USD 8 billion. However, after the 2008-2009 global financial crisis, this process has stopped.

The main problems in deciding the issue of attracting investment resources for project financing based on asset securitization are the determination of the bond circulation period, which 
should be related to the project life cycle duration, and the yield rates, the level of which should take into account not only the future profitability of the project, but also the potential investor interests. In addition, it should be borne in mind that the base rate includes the risk of the country, which in recent years is associated with political risks, and the ABS spread.

Based on the analysis of issuing the bonds of the external state loan in the period 2015-2018 by the government of Ukraine, it can be assumed that the coupon rate on commercial structured bonds can be set at $6-7 \%$. However, taking into account country risks and ABS-spread, which in recent years has fluctuated within $1-1.5 \%$, it should be raised to $7.0-8.5 \%$.

Based on the analysis carried out, the authors developed a structure of expenses for issuance of securitized bonds in Ukraine calculated for bond issues in the amount of USD 50 million, including payment to investors of bond income, based on the annual coupon rate, non-recurring costs (for service company fee, auditor, paying agent, rating review, etc.) and recurrent expenses (for legal advice, creation of an SPV company, an audit company conclusion, rating assignment, bond listing on the stock exchange, etc.) (Table 2).

The calculations lead to the conclusion that, based on the estimated cost of the investment project of USD 50 million, the one-off costs for issuing securitized assets to attract the appropriate amount of resources will be approximately USD 450,000-1,000,000; and recurrent expenses will amount to USD 300-850 thousand.

In order to reduce the securitization risks and stimulate project financing in Ukraine, it is necessary to create reserve funds, in particular, for insurance against political risks, as well as to cover the risks of the service company. In addition, a regulatory framework requires further improvement that regulates defining the organizational and legal form of SPV, the taxation of investors, the methodological support for portfolios of assets subject to securitization, etc.

According to the world practice, bank guarantees, letters of credit, long-term contracts, contracts on special terms, special account deposits, escrow accounts, reserve loans, etc. are the most common tools used to manage project risks (The Multilateral Investment Guarantee Agency, 2010).

The analysis of the National Bank of Ukraine factual data shows that in 2016, Ukrainian banks received 365 guarantees worth UAH 20.5 bln and issued 11,682 guarantees at the amount of UAH 13.1 billion. As of January 1, 2017, Ukrainian banks registered 813 issued letters of credit at the amount of UAH 16.1 billion and received 770 letters of credit at the amount of UAH 10.2 billion. Compared to 2015 , the number of letters of credit granted and received increased by $21.3 \%$, but their amount de-

Table 2. Calculated expenditure structure for issuance of corporate securitized bonds in Ukraine (in terms of bond issuance equal to USD $50 \mathrm{mln}$ )

Source: Calculated by the authors.

\begin{tabular}{|c|c|c|}
\hline Indicators & Expenditure types & $\begin{array}{l}\text { Value: basis points based on } \\
\text { the emission volume (bp); } \\
\text { USD thous. }\end{array}$ \\
\hline Outgoing payments & $\begin{array}{l}\text { Bond yield payment (coupon rate in terms of country risk } \\
\text { and ABS spread) }\end{array}$ & $700-850 \mathrm{bp}$ \\
\hline \multirow{5}{*}{$\begin{array}{l}\text { Recurrent expenses during } \\
\text { the bond circulation period in } \\
\text { terms of the emission volume of } \\
\text { securitized bonds }\end{array}$} & Service company fee & $50-150 \mathrm{bp}$ \\
\hline & Payment for management of assets pledged & $10-30$ USD thous. \\
\hline & Payment for auditing services & $15-30$ USD thous. \\
\hline & Payment for rating revision services & $10-20$ USD thous. \\
\hline & Payment for paying agent services & $10-20$ USD thous. \\
\hline \multirow{6}{*}{ Non-recurrent expenditures } & Legal advice & $100-400$ USD thous. \\
\hline & Expenses for SPV-company establishment & $50-60$ USD thous. \\
\hline & Auditing report on the securitized bonds issue & 20-50 USD thous. \\
\hline & Assigning a rating to each bond tranche & $5-10 \mathrm{bp}$ \\
\hline & Securitized bond listing on the stock exchange & $5-20$ USD thous. \\
\hline & Bond placement on the market & $50-100$ bp \\
\hline
\end{tabular}


Table 3. Letters of credit transactions of Ukrainian banks in the period 2016-2017 (at the beginning of the year)

Source: Estimated by the authors using the NBU statistics (https://bank.gov.ua/control/uk/publish/article?art_id=66326\&cat_id=66322)

\begin{tabular}{|c|c|c|c|c|c|c|c|c|}
\hline \multirow{3}{*}{ Indicators } & \multicolumn{4}{|c|}{ Number of letters of credit, units } & \multicolumn{4}{|c|}{ Amount of letters of credit, UAH bln } \\
\hline & \multicolumn{2}{|c|}{ Total } & \multicolumn{2}{|c|}{$\begin{array}{l}\text { Including those in } \\
\text { national currency }\end{array}$} & \multicolumn{2}{|c|}{ Total } & \multicolumn{2}{|c|}{$\begin{array}{l}\text { Including those in } \\
\text { national currency }\end{array}$} \\
\hline & 2016 & 2017 & 2016 & 2017 & 2016 & 2017 & 2016 & 2017 \\
\hline Letters of credit given to banks & 711 & 813 & 235 & 374 & 13.7 & 16.1 & 0.4 & 0.9 \\
\hline $\begin{array}{l}\text { Letters of credit received by } \\
\text { banks }\end{array}$ & 594 & 770 & 266 & 480 & 15.3 & 0.2 & 0.5 & 1.0 \\
\hline Total & 1,305 & 1,583 & 501 & 854 & 29.0 & 26.3 & 0.9 & 1.9 \\
\hline
\end{tabular}

creased by $9.3 \%$. At the same time, the cost of one granted letter of credit increased from UAH 19.27 million up to UAH 19.80 million, that is, by $2.75 \%$, and the cost of one issued letter of credit decreased from UAH 25.76 million up to 13.25 million, that is, by $48.56 \%$. In addition, the share of letters of credit issued in foreign currency decreased by 2.7 percentage points, and the proportion of letters of credit received in foreign currency - by 6.5 percentage points. At the same time, the cost of one granted letter of credit in foreign currency increased by $29.91 \%$, and the cost of one received letter of credit decreased by $29.70 \%$ (Table 3 ).

It shouldalsobenoted that during theimplementing investment projects in order to increase the effectiveness of securitization risk management, the guarantees and credit derivatives used must be irrevocable, unconditional and directly related to a specific requirement (a pool of claims) in order to prevent the cost of the provided protection against risks from increasing. If the credit protection instrument is denominated in a currency other than the national one, the amount of the secured credit requirement in calculating the regulatory capital of the bank should be reduced by an appropriate discount, the recommended standard rate of which is $8 \%$ (The Bank for International Settlements, 2004).

In order to manage currency risks arising during the implementing investment projects, repaying loans and paying interest on them, project participants can use a variety of methods for their hedging based on the use of derivatives of currency instruments. The most acceptable for these purposes in Ukraine at present, in the authors' opinion, are forward contracts, currency swaps and over-the-counter option (OTC option).

The main areas to use these instruments are the conversion of exported capital, lending, the purchase of foreign issuer securities or securities issued in foreign currency, support of commercial offers for contracts the value of which is expressed in foreign currency, and repatriation of the profits of the investment project participants.

The use of currency futures by investment companies when hedging project financing risks is limited due to the fact that they circulate on the exchange market according to a standard specification, and they are mainly intended for currency exchange and financial transactions for the purpose of generating income. Individual participants in the investment project can use these tools to manage internal risks in order to prevent currency losses.

The analysis made it possible to conclude that the currency market liberalization in Ukraine in the period 2016-2017 made the use of foreign exchange derivatives more active. If, in 2014, the amount of buying and selling foreign currency on the basis of foreign exchange derivatives was only USD 152.4 million, then, in 2017, it increased almost six-fold. At the same time, the use of currency swaps increased by 12.71 , and over-the-counter options by 8.63 times (Table 4 ).

Until2017, thelargest share in the currency derivatives structure was held by forward transactions, the share of which was $65.6 \%$ in 2016. However, in 2017, due 
Table 4. Use of currency derivatives by Ukrainian banks to hedge currency risks in the period 20122017, USD mln

Source: Estimated by the authors using the NBU (https://bank.gov.ua/doccatalog/document?id=54615270) and Ukrainian commercial banks data.

\begin{tabular}{|c|c|c|c|c|c|}
\hline Types of currency derivatives & 2014 & 2015 & 2016 & 2017 & $\begin{array}{c}\text { Growth } \\
\text { in } 2017 \\
\text { compared to } \\
2015 \text {, times }\end{array}$ \\
\hline Forward contracts & 103.7 & 274.7 & 583.1 & 327.8 & 3.16 \\
\hline Currency swaps & 38.9 & 91.2 & 273.6 & 494.3 & 12.71 \\
\hline Over-the-counter options & 9.8 & 17.3 & 32.7 & 84.6 & 8.63 \\
\hline Total & 152.4 & 383.2 & 889.4 & 906.7 & 5.95 \\
\hline
\end{tabular}

to continued liberalization of the foreign exchange market, this indicator fell to $36.2 \%$. It should also be noted that agreements for up to two weeks prevailed in the structure of transactions for buying foreign currency on a forward basis, and for sales from two weeks to two months, that is, most operations were short-term.

In 2017, as compared to 2016, the volume of swap transactions which were used to hedge medium-term and long-term risks, increased from USD 273.6 million to USD 494.3 million. In the structure of swap operations, the share of payments in euro has increased from 6\% in 2014 to $12 \%$ in 2017 , however, the interest rate on the swap transactions, although it declined in 2017 compared to 2016 in the dollar from $17.1 \%$ to $12.1 \%$, and in the euro from $15.3 \%$ to $12.0 \%$, is still quite high, which hinders the use of this instrument to hedge currency risks of project financing.

At the same time, despite the significant increase in the use of derivative currency instruments in Ukraine, this is still not enough to ensure an effective hedging of the entire variety of currency risks that arise in project financing.

It should also be noted that the main prerequisites for the project financing implementation are: a stable economy; a stable banking sector; stability of the national monetary unit; favorable investment climate; long-term and stable business relations between banks, investors and their partners; a high level of confidence between creditors; solvency and reliability of all the project agreement participants.

\section{CONCLUSION}

This research allows to draw a conclusion that in order to improve the investment climate and risk management of project financing in Ukraine, it is necessary to use more widely unconventional tools that allow investors to protect themselves against possible losses when implementing the investment project.

Calculations of the effective use of convertible bonds for the issuer and the investor, taking into account the mutual redistribution of financial risks, have shown that currently in Ukraine the potential savings of the convertible bond issuer may amount to approximately $3.8 \%$ of the volume of their issue, and the potential income of the investor is about $14.8 \%$.

Based on the analysis of prospects for using the asset securitization method in Ukraine with the aim to attract additional resources and manage project risks, an approximate structure of expenses for the implementing and servicing the structured bonds issue per USD 50 million has been developed, which includes the payment of income on bonds to investors, annual coupon rates at the level of $7.0-8.5 \%$, nonrecurring expenses in the amount of approximately 450-1,000 thousand US dollars and recurrent expenses in the amount of about USD 300-850 thousand. 
In order to reduce the securitization risks and stimulate project financing in Ukraine, it is proposed to create reserve funds for insurance against political risks, as well as to cover the service company risks. In addition, further improvement of the legislation is necessary in order to regulate the organizational and legal form of SPV, the taxation of investors, the methodological support for the formation of asset portfolios subject to securitization, etc.

The analysis of the Ukrainian banks' experience showed that the use of letters of credit in 2016 compared to 2015 increased by $21.3 \%$, including in the national currency - by $70.5 \%$, which is an indicator of increased investor attention to investment risk management.

The analysis showed that forward contracts, currency swaps and over-the-counter foreign exchange options are the most acceptable instruments for hedging foreign exchange risks of project financing. It is substantiated that the main directions of using these instruments to hedge foreign exchange risks are the conversion of exported capital, lending, the acquisition of securities of foreign issuers, support of commercial offers for contracts denominated in foreign currency, and repatriation of the profits of the investment project participants.

The analysis also indicated that due to the Ukrainian currency market liberalization, the use of foreign exchange derivative in 2017 compared to 2014 increased almost six times. There were the highest rates of increase in the use of currency swaps and over-the-counter options, denominated in euros. However, the cost of hedging using these currency instruments still remains quite high, which constrains their application for risk management of project financing.

The study made it possible to conclude that in using hybrid financial instruments to manage the project financing risks, further improvement of methodological approaches is needed, as well as justification of the methodological principles of hedging financial risks affecting both capital and activities of all participants of the investment project throughout all phases of its implementation.

\section{REFERENCES}

1. Basel Committee on Banking Supervision (2011, June). Principles for the Sound Management of Operational Risk. Retrieved from https://www.bis.org

2. Bessis, J. (2015). Risk management in banking (4th ed.). Wiley.

3. BIS (2004). International Convergence of Capital Measurement and Capital Standards: A Revised Framework. Retrieved from https://www.bis. org/publ/bcbs107.htm

4. Boberski, V. (2010). Community Banking Strategies: Steady Growth, Safe Portfolio Management, and Lasting Client Relationships. Hoboken, New Jersey: John Wiley \& Sons, Inc.

5. Crouhy, M., Galai, D., \& Mark, R. (2005). The Essentials of Risk Management. NY: McGraw-Hill.
6. Davidson, A., Sanders, A., Wolff, L.-L., \& Ching, A. (2004). Securitization: Structuring and Investment Analysis. Hoboken, New Jersey: John Wiley \& Sons, Inc.

7. Docherty, A., \& Viort, F. (2013). Better Banking: Understanding and Addressing the Failures in Risk Management, Governance and Regulation. Hoboken, New Jersey: John Wiley \& Sons, Inc.

8. Fabozzi, F. J. (1996). Asset-Backed Securities. Hoboken, New Jersey: John Wiley \& Sons, Inc.

9. Ghosh, A. (2012). Managing Risks in Commercial and Retail Banking. Hoboken, New Jersey: John Wiley \& Sons, Inc.

10. Golin, J., \& Delhaise, P. (2013). The Bank Credit Analysis Handbook: A Guide for Analysts, Bankers and Investors (2nd ed.).
Hoboken, New Jersey: John Wiley \& Sons, Inc.

11. Jobst, A. (2008). What Is Securitization? Finance \& Development, September, 48-49.

12. King, B. (2014). Breaking Banks. The Innovators, Rogues, and Strategists Re-booting Banking. Hoboken, New Jersey: John Wiley \& Sons, Inc.

13. Kothari, V. (2006). Securitization: The Financial Instrument of the Future. Hoboken, New Jersey: John Wiley \& Sons, Inc.

14. Mishchenko, S. V., Naumenkova, S. V., \& Lon, I. M. (2016). Монетарні цикли в економіці України [Monetarni tsykly v ekonomitsi Ukrainy]. Aktualni Problemy Ekonomiky, 11, 363-372.

15. Mishchenko, V. I., Naumenkova, S. V., \& Shapoval, O. A. (2016) Сек'юритизація споживчих 
кредитів [Sekiurytyzatsiia spozhyvchykh kredytiv]. Aktualni Problemy Ekonomiky, 12, 311-321.

16. Moenjak, T. (2014). Central Banking: Theory and Practice in Sustaining Monetary and Financial Stability. Wiley Finance Series.

17. Sokolov, B.I. \& Sokolova, S.V. (2016). Эволюция парадигмы государственного долга [Evolyucija paradigmy gosudarstvennogo dolga]. Aktualni Problemy Ekonomiky, 5, 49-56.
18. Weltman, J. (2015). Country risk: Why betting on Ukraine is for the fortuitous or foolhardy. Washington.

19. World Bank Group (2010) Investment Guarantee Guide. Multilateral Investment Guarantee Agency. Retrieved from https://www. miga.org/documents/IGG_English_final.pdf

20. World Bank Group (2012, March). MIGA's Non-Honoring of Sovereign Financial Obligations Product. Multilateral Investment Guarantee
Agency. Retrieved from https://www. miga.org/investment-guarantee

21. Yehorycheva, S., Kolodiziev, O., \& Prasolova, S. (2017). Actual problems of the capital stability management in the Ukraine's banking system. Banks and Bank Systems, 12(2), 60-67. https://doi. org/http://dx.doi.org/10.21511/ bbs.12(2).2017.06

22. Yescombe, E. R. (2014). Principles of Project Finance (2nd ed.). YCL Consulting Ltd. 